九州大学学術情報リポジトリ

Kyushu University Institutional Repository

\title{
Trends of House Construction and Wood Industries after the Asian Economic Crisis in Korea
}

Choi, Soo Im

Laboratory of Forest Policy, Division of Forest Environment and Management Sciences, Department of Forest and Forest Products Sciences, Graduate School of Bioresource and Bioenvironmental Sciences, Kyushu University

Sakai, Masahiro

Laboratory of Forest Policy, Division of Forest Environment and Management Sciences,

Department of Forest and Forest Products Sciences, Faculty of Agriculture, Kyushu University

Okamori, Akinori

Laboratory of Forest Policy, Division of Forest Environment and Management Sciences,

Department of Forest and Forest Products Sciences, Faculty of Agriculture, Kyushu University

Kang, Hag Mo

Kyonggi-do Forest Environment Research Station

https://doi.org/10.5109/24470

出版情報: 九州大学大学院農学研究院紀要. 47 (1)，pp.167-178，2002-10-30. Kyushu University バージョン：

権利関係: 
J. Fac. Agr., Kyushu Univ., 47 (1), 167-178 (2002)

\title{
Trends of House Construction and Wood Industries after the Asian Economic Crisis in Korea
}

\author{
Soo Im CHOI*, Masahiro SAKAI, Akinori OKAMORI and Hag Mo KANG** \\ Laboratory of Forest Policy, Division of Forest Environment and Management Sciences, \\ Department of Forest and Forest Products Sciences, Faculty of Agriculture, \\ Kyushu University, Fukuoka 812-8581, Japan. \\ (Received June 21, 2002 and accepted June 25, 2002)
}

\begin{abstract}
The economic crisis of Korea occurred from the second half of 1997 had direct and serious influence all over the domestic economy. This study considered what influence change of the housing construction that determines wood demand, and the exchange rate that are the main causes of an economic crisis had on timber supply and demand structure or wood industrial structure. In results, rapid dullness of the housing construction activity under an economic crisis brought about the big reduction of wooden product demand including the plywood. In addition, although the sudden drop of an exchange rate raised the imported wood price and brought about reduction of the imported timber volume in 1998, it raised the domestic price of wooden products to $30 \%$ or more with the rise of a production cost to wood industries, such as plywood which depends for a great portion of product production raw material on imported timber, and brought about retreat of wood industry. However, in contrast with dullness of such wood industry, in order that flooring industry might sell the apartment by the housing construction company amid economic depression, the demand in the form which contains flooring in basic specification spread, and the demand of a flooring product was greatly expanded also under the economic crisis.
\end{abstract}

\section{INTRODUCTION}

In Korea, plywood industry was specified to be export specialization industry as part of an economic development plan from the 1960s. Timber supply \& demand and wood industry have been greatly expanded focusing on plywood processing deal trade. Since strengthening of the material timber export regulation in the wood resources possession country began from the 1980 s, wood industry went to a decline by the big environmental change involving a raw material supply problem.

However, due to expansion of the domestic industries and the infrastructure institution from 1980s, and the increase in housing construction, wood industry was changed export led type by the 1970s to the domestic demand led type consisting mainly of engineering works and housing construction. By the way, since the domestic construction activities the domestic economic crises generated late in 1997 that are the main demand of timber stagnated and the import price rose by the fall of an exchange rate, wood industry would be pressed for reorganization.

On the other hand, previous studies had the wood industry centering on plywood.

\footnotetext{
* Laboratory of Forest Policy, Division of Forest Environment and Management Sciences, Department of Forest and Forest Products Sciences, Graduate School of Bioresource and Bioenvironmental Sciences, Kyushu University, Fukuoka 812-8581, Japan.

** Kyonggi-do Forest Environment Research Station, Osan, 447-290, Korea.
} 
Kim (1994) and Jung (1993) are analysis of a structural change of plywood industry, and Kim (1991), Kim (1997) and Choi (2001) are analyzed of the supply problem of raw material. However, Joo (1998) showed that change of an exchange rate had big influence on a price and the volume of imported timber, as a result of predicting the supply and demand of timber, lumber and plywood using the analysis model of a forest products market.

In this study, the domestic economy change after an economic crisis analyzes what timber supply and demand, and wood industry were affected paying attention to change of the exchange rate which are the main causes of an economic crisis and housing construction section, being based on such precedence studies.

\section{RESULTS AND DISCUSSION}

\section{Economic Crisis and the Trend of Housing Construction}

1) Korean Economy under the Economic Crisis

The Korean economy has accomplished economic growth in the highest growth rate with the economical development 5 years plan that started in 1962.

However, a rapid secession of foreign capital was caused from the second half of 1990 because of, such as current balance a deficit, continuous bankruptcy of the business enterprise in and outside the country, and accumulation of the huge bad loans of a financial institution. For this reason, a won loses the reliability of domestic and international investment, and came to request support of a fund in liquidity from International Monetary Fund (IMF) late in 1997. The IMF management organization and the so-called economic crisis started (Hwang and Lee, 1999).

The fall of the won which caused the economic crisis caused the rise of an import price, the consumer prices increasing rate rose from $4.5 \%$ in 1997 to $7.5 \%$ in 1998 . And the GDP growth rate which was maintaining the level of $8 \%$ from the 1990 s fell to $-5.8 \%$ in 1998. Moreover, the per capita GNP was also reduced to the 6,700 dollars that was the level of 1990 (Table 1).

Table 1. Trends of economic indicators in Korea

\begin{tabular}{cccccc}
\hline Category & \multicolumn{5}{c}{ Year } \\
\cline { 2 - 6 } & 1995 & 1996 & 1997 & 1998 & 1999 \\
\hline Real GDP growth rate (\%) & 8.9 & 6.8 & 5.0 & -5.8 & 10.7 \\
Per capital GNP (US\$) & 10823 & 11823 & 10307 & 6742 & 8581 \\
Real GNP growth rate (\%) & 8.1 & 4.8 & 2.1 & -8.8 & 8.9 \\
Exchange rate (Won) & 774.7 & 844.2 & 1415.2 & 1207.8 & 1145.4 \\
Unemployment rate (\%) & 2.0 & 2.0 & 2.6 & 6.8 & 6.3 \\
Amount of exports(100 million US\$) & 1246 & 1300 & 386 & 1318 & 1436 \\
Amount of imports(100 million US\$) & 1291 & 1449 & 1418 & 906 & 1197 \\
Current balance (100 million US\$) & -85 & -230 & -82 & 400 & 250 \\
\hline
\end{tabular}

Source: National Statistical Office, 2001; The Bank of Korea, 2001.

2) Trends of Housing Construction

Since the housing construction in Korea followed with economic development and industrialization and urbanization advanced it quickly from the 1980s, and the housing 
shortage difficult problem produced it in the larger cities. In order to solve such the housing shortage problem, and the government advances supply expansion centering on the high apartment house, the total housing construction number of houses is 750,000 to be the greatest ever, and an apartment occupied 67\% among those in 1990 (Fig. 1).

However, while domestic economy entered into rapid dullness from the second half of 1997, construction investment and consumption also hung low, and the total housing construction number of houses for 1998 years decreased to the level of the second half of the 1980s (310,000 houses) which decreased 49\% of contrast for 1997 years. Moreover, about 110,000 unsold houses existed in June 1998 (Yoon et al., 1998).

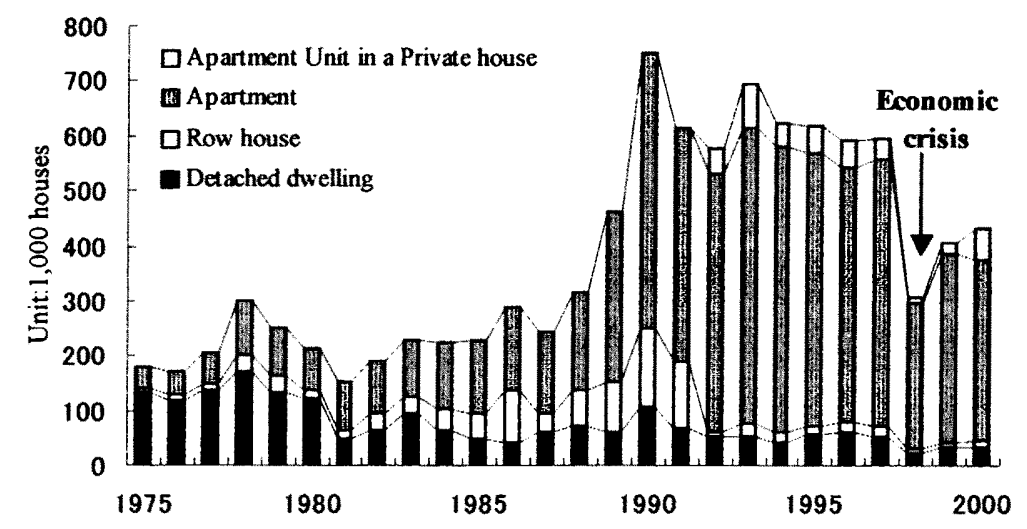

Fig. 1. Trends of housing unit construction by type (National Statistical Office, 2001)

\section{3) Deregulation in Connection with Housing Construction}

The economic crisis resulted in a big change not only to decreasing the housing construction number of houses but also to the environment involving a housing market.

First, capital liberalization was approached as conditions for the financial support from IMF, and while liberalization of real estate acquisition, the housing sale in lots, rental service, etc. which the foreigner was made to restrict until now were permitted. Hence, the foreigners' investing activities were opened widely (Hwang and Lee, 1999). Furthermore, the Korean government abolished various regulations, such as a report of land dealing, and permission, for full liberalization of a housing sale in lots price at first in order to activate the housing market that stagnated under the economic crisis (Yoon et al., 1998).

As for the abolition of such various regulations, an inflow of the capital which competition between the housing industry and a foreign country that switches from house supply of government leadership to the private supply system, and it is expected.

\section{Trend of Timber Supply \& Demand and Wood Industry}

1) Timber Supply and Demand 
(1) Timber demand

The feature of the timber demand by the 1970s in Korea was the plywood processing deal trade term that the scale of wood industry expanded focusing on plywood processing deal trade, and wood import increased. That is, extensive import of the tropical wood is carried out, and plywood was processed and exported at the country. For this reason, $55 \%$ of the amount of wood demand for 1975 years $\left(3,580,000 \mathrm{~m}^{3}\right)$ is an object for export, and $90 \%\left(3,230,000 \mathrm{~m}^{3}\right)$ was turned to the materials of the plywood for export (Table 2$)$.

However, when it entered in the 1980 , while the wood resources possession country developed the forest products industry of its own country including Indonesia which is a logs supply place, curtailment of the amount of felling and the log export embargo measure were started for environmental protection. For this reason, Korean wood industry declined quickly while losing competitive power internationally, and timber supply and demand structure also changed.

After that, although the timber demand for export was decreasing every year, in contrast with this, domestic wood demand expanded by expansion of the domestic paper \& pulp industry, engineering works and housing construction in the 1980s. That is, amount of domestic timber demand increased from $2,700,000 \mathrm{~m}^{3}$ in 1975 to $9,850,000 \mathrm{~m}^{3}$ in 1991 , and recorded the highest ever. The export led timber demand structure centering on the so-called plywood processing deal trade in the 1970 s changed from the 1980 s to the domestic demand initiative type.

However, since domestic economy lapsed into dullness from the second half of 1997 , activity of engineering works and housing construction also reduced, and the amount of wood demand in 1998 decreased to $5,800,000 \mathrm{~m}^{3}$ (38\% reduction of contrast of the previous year). Timber demand is returned to the level before an economic crisis because economy changed to the recovery tendency after 1998.

Table 2. Demand and supply of timber (Unit: $1,000 \mathrm{~m}^{3}$ )

\begin{tabular}{|c|c|c|c|c|c|c|c|c|c|c|c|c|c|}
\hline \multirow{3}{*}{ Year } & \multirow{3}{*}{ Total } & \multicolumn{8}{|c|}{ Demand } & \multirow{2}{*}{\multicolumn{4}{|c|}{$\frac{\text { Supply }}{\text { Round log }}$}} \\
\hline & & \multirow[b]{2}{*}{$\begin{array}{l}\text { Sub- } \\
\text { total }\end{array}$} & \multirow[b]{2}{*}{$\begin{array}{l}\text { Pit } \\
\text { prop }\end{array}$} & \multicolumn{2}{|c|}{ Domestic } & \multicolumn{3}{|c|}{ Export } & \multirow[b]{2}{*}{$\begin{array}{l}\text { Sawn- } \\
\text { wood }\end{array}$} & & & & \\
\hline & & & & $\begin{array}{l}\text { Pulp } \\
\text { wood }\end{array}$ & $\begin{array}{l}\text { Ply- } \\
\text { wood }\end{array}$ & $\begin{array}{l}\text { General } \\
\text { use }\end{array}$ & $\begin{array}{l}\text { Sub- } \\
\text { total }\end{array}$ & $\begin{array}{l}\text { Ply- } \\
\text { wood }\end{array}$ & & $\begin{array}{l}\text { Sub- } \\
\text { total }\end{array}$ & \multicolumn{2}{|c|}{$\begin{array}{l}\text { Dome-Import } \\
\text { stic }\end{array}$} & $\begin{array}{l}\text { Waste } \\
\text { wood }\end{array}$ \\
\hline 1975 & 6465 & 2889 & 542 & 188 & - & 2159 & 3576 & 3226 & 350 & 6 & 896 & 5119 & 450 \\
\hline 1980 & 7750 & 5785 & 515 & 546 & 1603 & 3121 & 1965 & 1753 & 212 & 7750 & 1008 & 6141 & 601 \\
\hline 1990 & 9423 & 9121 & 512 & 479 & 1849 & 6281 & 302 & 40 & 262 & 9423 & 1138 & 8285 & 640 \\
\hline 1995 & 9284 & 8939 & 139 & 1275 & 1300 & 6225 & 345 & 186 & 159 & 9284 & 1055 & 8229 & 1526 \\
\hline 1996 & 9225 & 8893 & 109 & 1287 & 1334 & 6163 & 332 & 159 & 173 & 9225 & 1195 & 8030 & 1704 \\
\hline 1997 & 9328 & 8987 & 104 & 1253 & 1611 & 6019 & 341 & 79 & 262 & 9328 & 1062 & 8266 & 1723 \\
\hline 1998 & 5798 & 5265 & 110 & 992 & 859 & 3304 & 533 & 262 & 271 & 5798 & 1428 & 4370 & 1185 \\
\hline 1999 & 8317 & 7836 & 117 & 1361 & 1051 & 5307 & 481 & 233 & 248 & 8317 & 1694 & 6623 & 1582 \\
\hline 2000 & 8327 & 7897 & 112 & 1295 & 1066 & 5424 & 430 & 179 & 251 & 8327 & 1592 & 6785 & 1816 \\
\hline
\end{tabular}

Source: Statistical Yearbook of Forestry, 2000.

Note: Total of demand and supply of timber is exclusive of waste wood. 


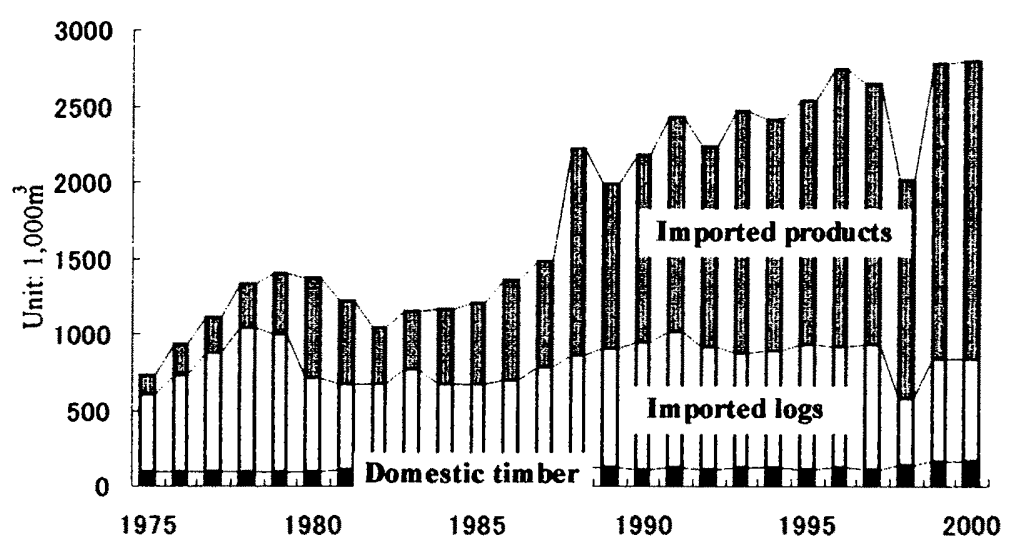

Fig. 2. Trends of timber demand and supply (Statistical Yearbook of Forestry, 2001)

(2) Timber Supply

Since economic development started in the desolate conditions of the forest resources in spite of the increase in timber demand, it did not pass over the amount of supply of domestic wood before and after $1,100,000 \mathrm{~m}^{3}$ in general, but timber supply has almost been dependent on imported wood. The volume of imported timber increased remarkably, when $6,380,000 \mathrm{~m}^{3}$ for 1975 entered in the $1990 \mathrm{~s}$, and it increased to $26,210,000 \mathrm{~m}^{3}$ in 1996 (Fig. 2). In additionally, as the structure of imported wood, the logs import type by the 1970 is changing from the 1980 to the manufactured products type.

However, causing the rise of an import price from the second half of 1997 by the fall of a won, and making the volume of imported timber restrict. The timber amount of supply started to decrease and was $18,650,000 \mathrm{~m}^{3}$ (27\% reduction of contrast of the previous year) in 1998. The log volume of import had a remarkable reduction in it at $4,370,000 \mathrm{~m}^{3}$ ( $47 \%$ reduction of contrast of the previous year).

2) Wood Industry

(1) Development Process of Wood Industry

Korean wood industry can be divided roughly in three stages until after an economic crisis from the 1960. The 1st term is an expansion term (1960 1980) wood industry grew up to be greatly by the cheap labor force with expansion of the plywood industry which processed imported log and was exported at the high economic growth term. The 2nd term is a stagnation term $(1981 \sim 1997)$ to which wood industry retreated with the fall of competitive power by the problem of wood import structure which surround raw material supply of tropical timber from the 1980s, and which changed remarkably, and wages rise. The 3rd term is the crisis (1998 1999) of the wood industry that caused management aggravation by generating of an economic crisis under the influence by the problem of raw material supply and demand, and the rise of a production cost (Fig. 3). 


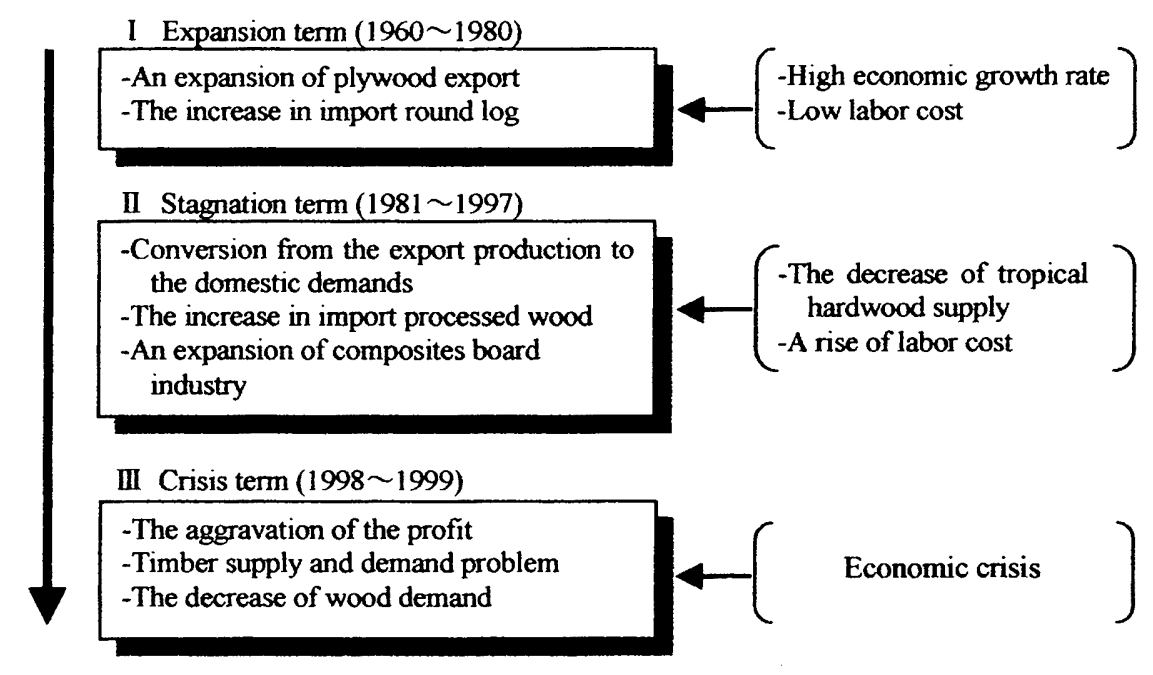

Fig. 3. Trends of the wood industry for the last four decades

(2) Plywood Industry

The plywood industry that was the pillar of the Korean wood industry was environmental change, which surrounds the supply problem of raw material from 1980s. The number of factories and the quantity of production began to decrease sharply, and 84 factories and $1,580,000 \mathrm{~m}^{3}$ in $1980 \mathrm{~s}$ decreased to 7 factories and $1,010,000 \mathrm{~m}^{3}$ in 1997. Furthermore, two factories were closed down under the influence of an economic crisis in 1998 , and the quantity of production decreased to $640,000 \mathrm{~m}^{3}$ (Table 3 ).

Table 3. Trend of plywood industry (Unit: $1,000 \mathrm{~m}^{\prime}$ )

\begin{tabular}{crrrrrrrrr}
\hline Classification & \multicolumn{1}{c}{ Year } \\
\cline { 2 - 9 } & 1970 & 1980 & 1990 & 1995 & 1996 & 1997 & 1998 & 1999 & 2000 \\
\hline No. of factories & 10 & 84 & 72 & 15 & 7 & 7 & 5 & 5 & 5 \\
Production & 1067 & 1575 & 1124 & 892 & 896 & 1014 & 641 & 735 & 747 \\
Export & 1055 & 953 & 154 & 101 & 100 & 54 & 141 & 135 & 99 \\
Import & - & 23 & 735 & 1307 & 1079 & 949 & 494 & 791 & 980 \\
\hline
\end{tabular}

Sourcc: Forestry Research Institute, Korea, 2001.

Although plywood production had been produced centering on the product with a thickness of less than $6 \mathrm{~mm}$ till the 1970s, since change of plywood materials and plywood production of the countries in Southeast Asia got into stride from the 1980s, the domestic plywood company set about the product production which is relatively competitive. That is, since domestic plywood demand increased with active engineering works and housing construction activity from the 1980 s, plywood production was converted into the production system centering on the plywood for concrete formwork with a thickness of $12 \mathrm{~mm}$ or 
more (Jung, 1993). The plywood production ratio of $12 \mathrm{~mm}$ or more to the amount of gross products was expanded from 36\% in 1980s to $97 \%$ in 1997 (Table 4).

Table 4. Production of plywood by thickness (Unit: $1,000 \mathrm{~m}^{3}$ )

\begin{tabular}{crrrrr}
\hline Year & Total & $<3.5 \mathrm{~mm}$ & $3.6 \sim 5.9$ & $6.0 \sim 11.9$ & $>12.0 \mathrm{~mm}$ \\
\hline 1980 & 1575 & 30 & 823 & 149 & 573 \\
1990 & 900 & 150 & 38 & 27 & 685 \\
1995 & 722 & 13 & 3 & 2 & 704 \\
1996 & 726 & 7 & 4 & 6 & 709 \\
1997 & 866 & 7 & 8 & 13 & 838 \\
1998 & 519 & 8 & 5 & 24 & 482 \\
1999 & 594 & 7 & 17 & 28 & 542 \\
2000 & 598 & 3 & 19 & 21 & 555
\end{tabular}

Source: Wood Panel Association, Korea, 2001.

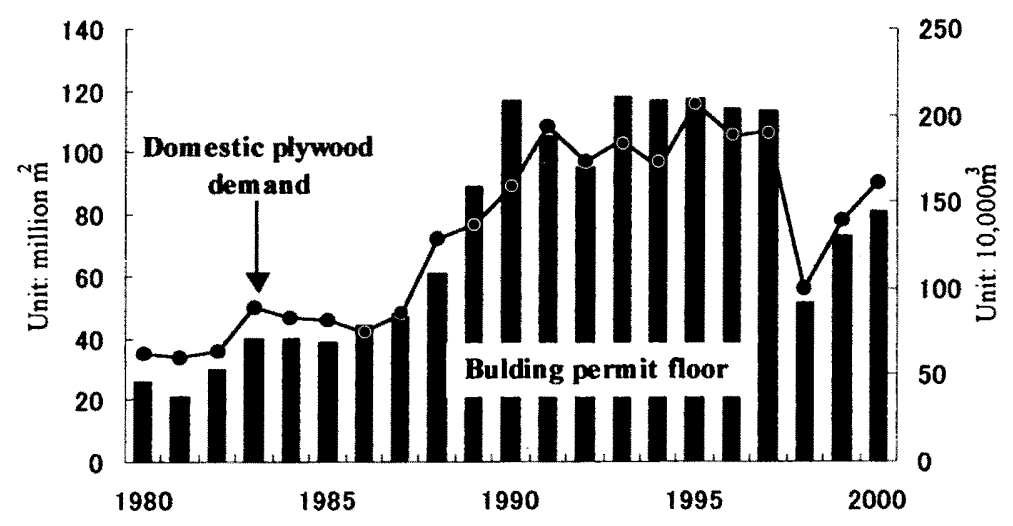

Fig. 4. Trends of domestic plywood demand and building permit floor (Statistical Yearbook of Forestry, 2001; National Statistical Office, 2001)

On the other hand, domestic plywood demand increased remarkably from $500,000 \mathrm{~m}^{3}$ in $1975 \mathrm{~s}$ to $1,750,000 \mathrm{~m}^{3}$ in 1990 , and the greatest ever was recorded by $2,090,000 \mathrm{~m}^{3}$ in 1995. However, plywood demand decreased from the second half of 1997 by dullness of construction activities in 1998 to 1 million $\mathrm{m}^{3}$ (47\% reduction of contrast of the previous year) (Fig. 4). For this reason, the plywood quantity of production for 1998s was set to $520,000 \mathrm{~m}^{3}$ that decreased $40 \%$ of contrast in the previous year.

(3) Composites Board Industry

It expanded Korean composites board industry by contrast quickly from the 1990s that plywood industry decreased with a peak of the 1980. As of 1999, PB (Particleboard) production company has four companies and five factories, and annual productive 
capacity is $680,000 \mathrm{~m}^{3}$. And MDF (Medium Density Fiberboard) production company has five companies and ten factories, and annual productive capacity amounts to $970,000 \mathrm{~m}^{3}$.

The Korean composites board product is mainly used for manufacture of furniture and a cabinets, etc. rather than the construction use. $\mathrm{PB}$ increased rapidly, after entering in the 1990 , and $170,000 \mathrm{~m}^{3}$ for 1990 expanded to $720,000 \mathrm{~m}^{3}$ in 1997 . Since MDF had a special quality of materials, which is easy to process its surface, they considered as the alternative material of plywood and $110,000 \mathrm{~m}^{3}$ for 1990 increased them to $730,000 \mathrm{~m}^{3}$ in 1997.

On the other hand, since composites board industry uses domestic lumber and plywood waste wood as materials, the quantity of production exists in the trend of the operating ratio of lumber and plywood industry. This decreased temporarily in 1998 to $\mathrm{PB}$ is $510,000 \mathrm{~m}^{3}$ (30\% reduction of contrast of the previous year), and MDF is $570,000 \mathrm{~m}^{3}$ ( $22 \%$ reduction of these contrast). As for the reason, it is mentioned that the waste wood amount of supply decreased and raw material reservation became difficult by decline in these operating ratios. However, PB increased to 670,000 and MDF increased to 840,000 in 1999 (Table 5).

Table 5. Production and import of composites board (Unit: $1,000 \mathrm{~m}^{3}$ )

\begin{tabular}{|c|c|c|c|c|c|c|c|c|}
\hline \multirow{2}{*}{ Classification } & & \multicolumn{7}{|c|}{ Year } \\
\hline & & 1986 & 1993 & 1996 & 1997 & 1998 & 1999 & 2000 \\
\hline \multirow{2}{*}{ No. of factories } & $\mathrm{P} \quad \mathrm{B}$ & - & 4 & 4 & 4 & 4 & 4 & 4 \\
\hline & MDF & - & 6 & 5 & 5 & 5 & 5 & 5 \\
\hline \multirow{2}{*}{ Production } & $\mathrm{P} \quad \mathrm{B}$ & 105 & 435 & 659 & 720 & 507 & 672 & 722 \\
\hline & MDF & 12 & 268 & 719 & 728 & 571 & 831 & 973 \\
\hline \multirow{2}{*}{ Import } & $\mathrm{P} \quad \mathrm{B}$ & - & 516 & 355 & 293 & 173 & 436 & 485 \\
\hline & MDF & - & 144 & 53 & 58 & 28 & 172 & 380 \\
\hline \multirow{2}{*}{ Domestic supply } & $\mathrm{P} \quad \mathrm{B}$ & 105 & 414 & 641 & 748 & 506 & 658 & 718 \\
\hline & MDF & 11 & 268 & 631 & 689 & 507 & 745 & 795 \\
\hline
\end{tabular}

Source: Statistical Yearbook of Forestry; Wood Panel Association, Korea, 2000.

\section{(4) Flooring Industry}

The flooring for residences in Korea appeared for the first time late in the 1980s, and change of the housing demand by the consumer was seen from the 1990s, as use of the flooring from a housing construction company, so spread of it had been increased. Furthermore, in order to sell the unsold and new apartment between house construction companies with liberalization of a housing sale in lots price under an economic crisis, competition of product differentiation in the form included in basic specification raised the flooring. For this reason, the demand of a flooring was expanded sharply not only in the existing high-class apartment but in medium and small apartment.

Production of the flooring is from a company including existing plywood and composites board industry, and one company in 1994 increased it to 12 companies in 1998 , and 20 companies in 2000 (Table 6). The quantity of production was sharply expanded from $70,000 \mathrm{~m}^{2}$ in 1995 to $230,000 \mathrm{~m}^{2}$ in 1998 which construction activities reduced fur- 
ther in 1997. As for the volume of imported $750,000 \mathrm{~m}^{2}$ in 1997 decreased by the rise of an import price in 1998 to $110,000 \mathrm{~m}^{2}$ ( 6.8 times reduction contrast of the previous year) (Fig. 5).

On the other hand, production of the domestic flooring is divided into Parquet Flooring and Laminate Flooring. Although the quantity of production is increasing every year in Parquet Flooring, as for a market share, 100\% by 1996 is falling to $86 \%$ in 1997 , and $73 \%$ in 1999 . Compared with this, 14\% market share in 1997 for Laminate Flooring, which was extended in the big market share to $29 \%$ and $30 \%$ in 1998 and 2000, respectively (Table 6).

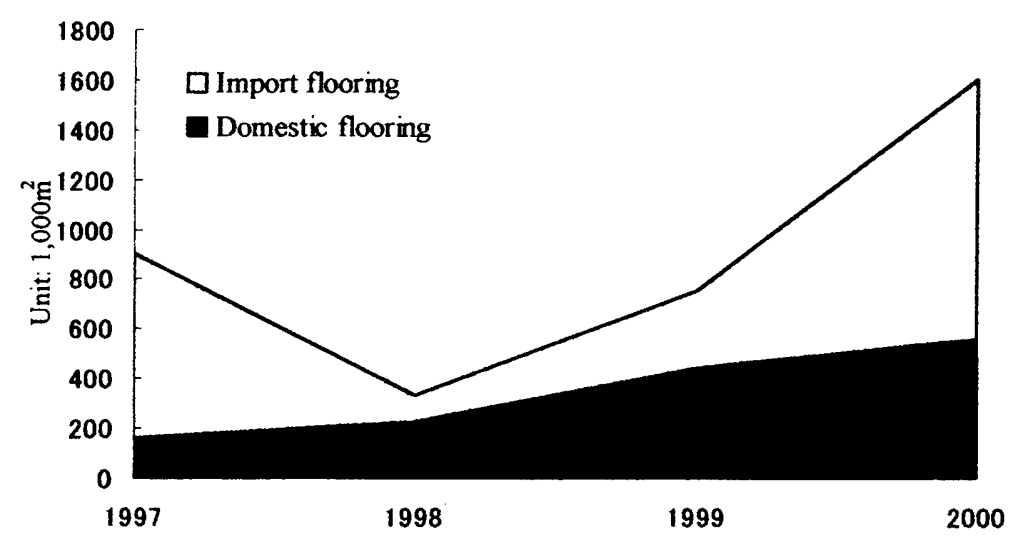

Fig. 5. Trends of flooring production and import (Forestry Research Institute, 2001)

Table 6. Share of domestic flooring (Unit: \%)

\begin{tabular}{ccccccc}
\hline Classification & \multicolumn{7}{c}{ Year } \\
\cline { 2 - 7 } & 1995 & 1996 & 1997 & 1998 & 1999 & 2000 \\
\hline No. of companies & 4 & 7 & 9 & 12 & 18 & 20 \\
Parquet flooring (\%) & 100.0 & 100.0 & 83.3 & 70.7 & 73.2 & 69.8 \\
Laminate flooring (\%) & - & - & 13.7 & 29.3 & 26.8 & 30.2 \\
\hline
\end{tabular}

Source: Forest Research Institute, Korea, 2001.

\section{CONSIDERATION}

Rapid change of an exchange rate was after the second half of 1997 the main causes of having had big influence on wood supply \& demand structure and wood industrial structure.

Table 7 shows how the production cost of wood industry went up by change of an exchange rate. As for the rate of a won, 805 won in 1996 fell to $1,400 \sim 1,600$ won 
(increase in $74 \% \sim 99 \%$ of 1996 contrast) in 1998. Then, each cost also increased greatly and, for lumber industry is the 1.9 times, pulp industry (chemistry pulp) is the 1.7 times, board industry (MDF) is the 1.8 times and plywood industry is the 1.6 times (Table 7).

Moreover, Table 8 shows how the wood price rose by change of an exchange rate. The rate of a won fell from 844 won late in 1996 rapidly late in 1998 to $1,200 \sim 1,400$ won (increase in $68 \%$ of 1996 contrast). Then, the logs of an import price were a maximum of $70 \%$ in 1998 , and the wooden products went up to $50 \%$. They were the main causes by which the logs volume of import in 1998 decreased to $47 \%$ of contrast in the previous year, because of the rise of such an import price (Table 8 ).

On the other hand, when the cause of change was seen according to wood industry, since plywood industry depended for the great portion of raw material on imported log, such as Radiate pine and Lauan, the rise of an import price brought about reduction of plywood demand, and making the expense burden of raw material increase. Although the composites board industry became difficult because of reduction of lumber \& plywood waste wood amount of supply as raw materials reservation, a part for short supply was replaced with domestic logs, and the board price rose with the price boost of domestic logs. Moreover, although the product of import boards brought about the rise of an import price with imported plywood when it entered in 1998, and since the price of the product

Table 7. Change of production cost index by an exchange rate

\begin{tabular}{ccccc}
\hline & \multicolumn{5}{c}{ Year } \\
\cline { 2 - 5 } Exchange rate & 1996 & & 1998 \\
(Won/U.S.dollar) & 805 & 1200 & 1400 & 1600 \\
\hline Plywood (\%) & 100 & 132 & 149 & 165 \\
M D F (\%) & 100 & 129 & 144 & 158 \\
Sawnwood (\%) & 100 & 144 & 167 & 189 \\
Chemical pulp (\%) & 100 & 141 & 161 & 182 \\
\hline
\end{tabular}

Source: Rural Economic Institute, Korea, 1998.

Note: 1) $1996=100$ (production cost index)

Table 8. Change of wood products price by an exchange rate (Unit: 1,000 Won)

\begin{tabular}{cccccc}
\hline & \multicolumn{5}{c}{ Year } \\
\cline { 2 - 6 } Exchange rate & Dec-96 & Dec-97 & Mar-98 & Jun-98 & Sep-98 \\
(WonU.S.dollar) & 844 & 1415 & 1379 & 1385 & 1374 \\
\hline Plywood 3 mm & 4.9 & 7.5 & 7.8 & 4.5 & 4.6 \\
Plywood 12 mm & 16.7 & 22.2 & 22.6 & 18.7 & 17.3 \\
P B 15 mm & 8.4 & 11.4 & 12.1 & 10.7 & 9.4 \\
M D F 3 mm & 3.1 & 4.5 & 4.9 & 4.4 & 4.3 \\
Import plywood 2.7 mm & 5.3 & 7.4 & 7.4 & 3.9 & 3.5 \\
Domesic log (Pine) & 100.0 & 106.0 & 108.8 & 112.7 & 11.3 \\
Hemlock & 150.0 & 168.0 & 255.0 & 222.0 & 222.0 \\
Lauan & 390.0 & 480.0 & 540.0 & 375.0 & 375.0 \\
Radiate pine & - & 123.0 & 180.0 & 195.0 & 195.0 \\
\hline
\end{tabular}

Source: Forestry Cooperatives, Korea, 1996, 1997, 1998. 
from Southeast Asia fell from the 1998 middle of the year, it was the cause in which import of wooden products recorded the greatest ever in 1999.

On the other hand, the demand change between the products in flooring industry was for the supply structure of raw material. That is, when adopting the flooring in medium and small apartment while calling at the housing construction company under an economic crisis, parquet flooring brought about demand reduction with the rise of a product price for depending for $90 \%$ or more of raw material on imported plywood. Since laminate flooring used HDF (High Density Fiberboard) which is a kind of a board product in contrast with this, that there was competitive power of a price compared with other products was the cause which demand expanded in 1998.

\section{CONCLUSIONS}

Korean economy was influenced according to the economic crisis generated late in 1997 , such as a rate of high prices, a rate of high exchange rate, a rate of high unemployment, and a rate of low growth. Such a remarkable economical change causes a rapid reduction of the housing construction centering on an apartment, and makes the demand of wooden products including the plywood mainly turned to concrete construction decrease.

When it entered in 1998, with the rapid fall of an exchange rate, the imported timber price rose and the timber volume of import brought about a rapid reduction. However, the wood industry that makes imported logs the main raw materials brought about retreat of wood industry, raising a domestic wooden products price to $30 \%$ or more with the rise of a production cost.

In contrast with retreat of such wood industry, in order that flooring industry might sell the apartment by the housing construction company in economic depression, the demand in the form which contains flooring in basic specification spread, and the flooring product brought about a big demand expansion under the economic crisis. Since laminate flooring, which utilization HDF (High Density Fiberboard) in it had the competitive power of a price, its expansion of demand was remarkable.

On the other hand, deregulation concerning the housing construction section and the diversification of a consumer's housing demand under an economic crisis, the increase in the new wood demand involving a housing construction section will be expected in the future as the demand of a flooring product expanded diversification of housing demand quickly.

\section{REFERENCES}

Choi, S. I., A. Okamori, and M. Sakai, 2001 Trends of timber demand supply in Korea until the Asian ecomomic crisis, Sci. Bull. Fac., Kyushu University, 55: 297-306.

Hwang, S. I and S. B. Lee, 1999 Adjustment reforms in Korea since the financial crisis II, Korea Institute for International Economic Policy.

Joo, L. W., S. Y. Lee, and H. S. Jeon, 1998 Future projection of trends in logs, sawnwood and plywood markets in the Republic of Korea, KRI Journal of Forest Science, 58: 93-103.

Jung, K. S 1993 A study on the structural change and international competitiveness of Korean plywood industry, DS thesis, Seoul National University.

Kim, J. S and H. T. Park, 1980 Study on the long-term demand projections for timber in Korea. Journal 
of Korea Forestry Society, 50: 29-35.

Kim, S. B 1988 A development process of wood industry in the Republic of Korea, Journal of Forest Economics, 114: 51-52.

Kim, S. B 1991 Korean wood industries and product imports, Forest Economy, 44(7): 16-25.

Kim, W. J and S. G. Jung, 1993 Study on production structures and measures for vitalization of plywood industry in Korea, KRI Journal of Forest Science, 48: 113-123.

Kim, W. J 1997 Impacts of Changes in Marketing Environment on the Primary Wood-Processing Industry in Korea, Proceedings of the XI World Forest Congress: The Economic Contribution of Forest to Sustainable Development. Volume 4.

Korea Rural Economic Institute 1994 Basic study for forest 100 years planning establishment, Korea Forest Service, $42-66$.

National Statistical Office 2001 [Online] www.nso.go.kr

Rosemarie, B and T. Bob, 1999 An Assessment of the South Korean Market for Value-Added Wood Products, College of Forest Resources University of Washington, CINTRAFOR Working Paper 71.

The Bank of Korea 2001 [Online] www.bok.or.kr

Yoon, J. Y., K. H. Shon, H. Y. Kim, and H. Y. Chun, 1998 Structural changes in the housing market and new direction for the housing policy, Korea Research Institute for Human Settlements.

Youn, Y. C and E. K. Kim, 1992 A study on the demand for timber in South Korea, Journal of Korean Forestry Society, 81(2): 124-138. 